ISSN (Online) 2710-3315

https://doi.org/10.20535/EHS.2021.233065

УДК 546.19+628.316.12

\title{
ОЧИЩЕННЯ ВОД ВІД АРСЕНУ(V) МАТЕРІАЛАМИ НА ОСНОВІ НАНОДИСПЕРСНОГО ЗАЛІЗА
}

\author{
А.І. Бондарєва, Ю.М. Холодько, В.Ю. Тобілко \\ Національний технічний університет України \\ «Київський політехнічний інститут імені Ігоря Сікорського» \\ пр. Перемоги, 37, Київ, 03056, Україна \\ e-mail: a.i.bondarieva@gmail.com
}

Серед неорганічних забруднювачів водного басейну найбільшу небезпеку для здоров'я людини становлять сполуки арсену, які відрізняються токсичністю та канцерогенною i мутагенною дією на живі організми. У поверхневі та підземні води As (V) може надходити як в результаті природного вилуговування із арсенвмісних порід, так і зі стічними водами підприємств кольорової металургії, викидами електростанцій, які використовують кам'яне вугілля, металопереробних заводів та ін. [1]. В окремих регіонах його вміст у природних водах коливається в межах до сотень мікрограм у 1 дм³ $^{3}$. Форма знаходження арсену у поверхневих $\mathrm{i}$ підземних водних об'єктах залежить від $\mathrm{pH}$ водного середовища, окисно-відновного потенціалу, концентрації розчиненого кисню. Так, в окиснювальних умовах переважають арсенатні сполуки типу $\mathrm{H}_{2} \mathrm{AsO}_{4}{ }^{-}$та $\mathrm{HAsO}_{4}{ }^{2-}$ [2].

Серед відомих методів очищення вод від неорганічних токсикантів особливої уваги заслуговують сорбційні, так як води дозволяють видаляти іони металів до рівнів ГДК і нижче. Сорбенти на основі нанорозмірного нульвалентного заліза $\left(\mathrm{Fe}^{0}\right)$ ефективно видаляють неорганічні токсиканти із забруднених вод [3]. Однак, здатність $\mathrm{Fe}^{0}$ до агрегації та окиснення, ускладнює реалізацію сорбційних процесів із застосуванням таких систем. Для вирішення даної проблеми рекомендується використовувати стабілізовані частинки $\mathrm{Fe}^{0}$, які отримують шляхом їх іммобілізації на неорганічні або органічні матриці. Перспективними є підложки на основі природних силікатів, наприклад, глинистих мінералів та цеолітів. В попередніх дослідженнях [4] було встановлено, що сорбенти на основі шаруватих і шарувато-стрічкових алюмосилікатів та нанозаліза характеризуються високою сорбційною здатністю до аніонів $\mathrm{Cr}(\mathrm{VI})$ та U(VI). Крім того, композити типу каолініт/Fe $\mathrm{F}^{0}$ успішно використані для очищення складних стічних вод, що містять суміш токсичних іонів $\mathrm{Cu}(\mathrm{II}), \mathrm{Cd}(\mathrm{II}), \mathrm{Co}(\mathrm{II}), \mathrm{Zn}(\mathrm{II})$ і $\mathrm{Cr}(\mathrm{VI})$ [5].

Метою даного дослідження було вивчити основні фізико-хімічні особливості видалення арсену(V) із забруднених вод з використанням сорбційних матеріалів на основі каолініту та нанорозмірного нульвалентного заліза.

Сорбенти на основі каолініту (K) та іммобілізованого нанодисперсного $\mathrm{Fe}^{0}$ одержували за методикою, описаною в роботі [6]. Для цього використовували очищений від домішок глинистий мінерал та розчин хлориду заліза (III) певної концентрації. Відновлення іонів $\mathrm{Fe}^{3+}$ проводили розчином борогідриду натрію $\mathrm{NaBH}_{4}$. Було отримано чотири зразка 3 масовим співвідношенням $\mathrm{Fe}^{0}$ до каоліну (К) 0,01:1, 0,05:1, 0,1:1 та 0,2:1. 
Для визначення мономінеральності природного глинистого мінералу та фазового складу модифікованих зразків використовували рентгенографічний метод аналізу. Дослідження проводили на дифрактометрі ДРОН-4-07 з двома щілинами Соллера в діапазоні 2-60² $2 \theta$ i відфільтрованим СuK $\alpha$-випромінюванням.

Вивчення морфології поверхні вихідного каолініту та композиційних матеріалів здійснювали за допомогою скануючої електронної мікроскопії (CEM Jeol JSM-5510LV).

Сорбційну здатність синтезованих зразків вивчали на прикладі іонів арсену (V) в діапазоні вихідних концентрацій 0.5-20 мг/дм³ у статичних умовах, при кімнатній температурі та співвідношенні твердої і рідкої фаз $\mathrm{T}: \mathrm{P}=1: 500$. Іонну силу $(\mathrm{I}=0,01)$ створювали $1 \mathrm{M} \mathrm{розчином}$ $\mathrm{NaCl}$. Величину $\mathrm{pH}$ модельних розчинів корегували $0,1 \mathrm{M}$ розчином $\mathrm{NaOH}$. Рівноважну концентрацію іонів As (V) визначали методом атомно-емісійної спектрометрії з індуктивнозв'язаною плазмою (Thermo Scientific iCAP 7400 ICP-OES, CША).

Для розрахунку ступеня очищення $(\mathrm{X}, \%)$ вод від забруднення арсеном використовували формулу:

$$
X=\frac{C_{\text {вux }}-C_{p i s H}}{C_{\text {sux }}} \cdot 100 \%
$$

Величину сорбції ( ${ }^{a}$, мг/г) арсенат-іонів розраховували за формулою:

$$
a=\frac{\left(C_{\text {вих }}-C_{\text {рівн }}\right) \cdot V}{m},
$$

де $C_{\text {вих }}, C_{\text {рівн }}$ - вихідна та рівноважна концентрації металу, мг/дм³ $V^{3}-$ об'єм розчину, дм³; $m$ - маса наважки сорбенту, г.

Рентгенографічним аналізом підтверджено мономінеральність вихідного каолініту та наявність шару сполук заліза на поверхні синтезованих зразків, які представляють собою, в основному, $\alpha-\mathrm{Fe}$, оксиди (FeO) та оксигідроксиди заліза (FeOOH) [7]. На рис. 1 представлені CЕМ-зображення каолініту (а) та модифікованого нанодисперсним залізом зразка (б). Отримані дані вказують на наявність часточок $\mathrm{Fe}^{0}$ на поверхні глинистого мінералу.
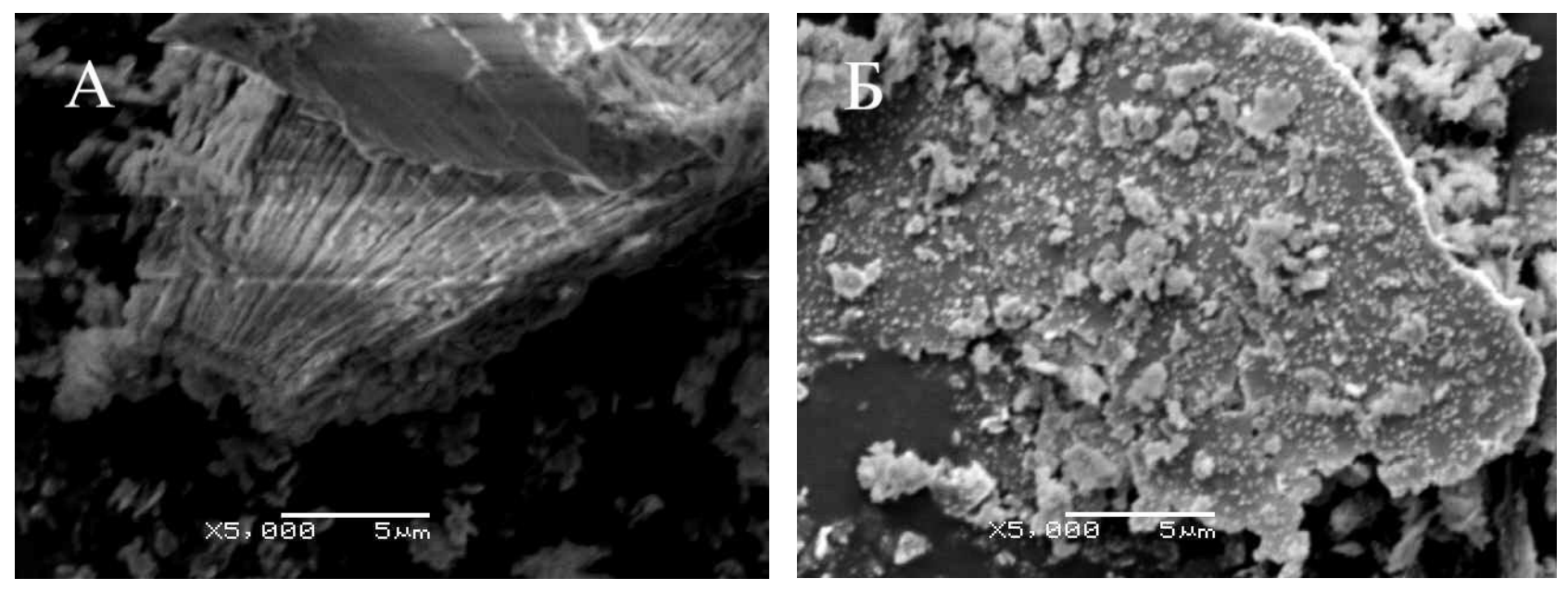

Рисунок 1. СЕМ-зображення структури вихідного (а) та модифікованого (б) каолініту

На рис. 2 зображено діаграму залежності ступеня очищення води від забруднення арсенатіонами синтезованими зразками з різним співвідношенням $\mathrm{Fe}^{0}$ до К. Вихідна концентрація Аs 
(V) у розчині становила 6 мг/дм², а величина $\mathrm{pH}=6$. Отримані дані свідчать про те, що зі збільшенням вмісту нанодисперсного $\mathrm{Fe}^{0}$ на поверхні каолініту зростає сорбційна здатність композитів. Так, максимальний ступінь очищення при даних умовах проведення експерименту спостерігається для сорбційного матеріалу із масовим співвідношенні $\mathrm{Fe}^{0}: \mathrm{K}=$ 0.2:1 і становить 97,74\%. Тому в усіх подальших дослідженнях використовували саме цей сорбент.

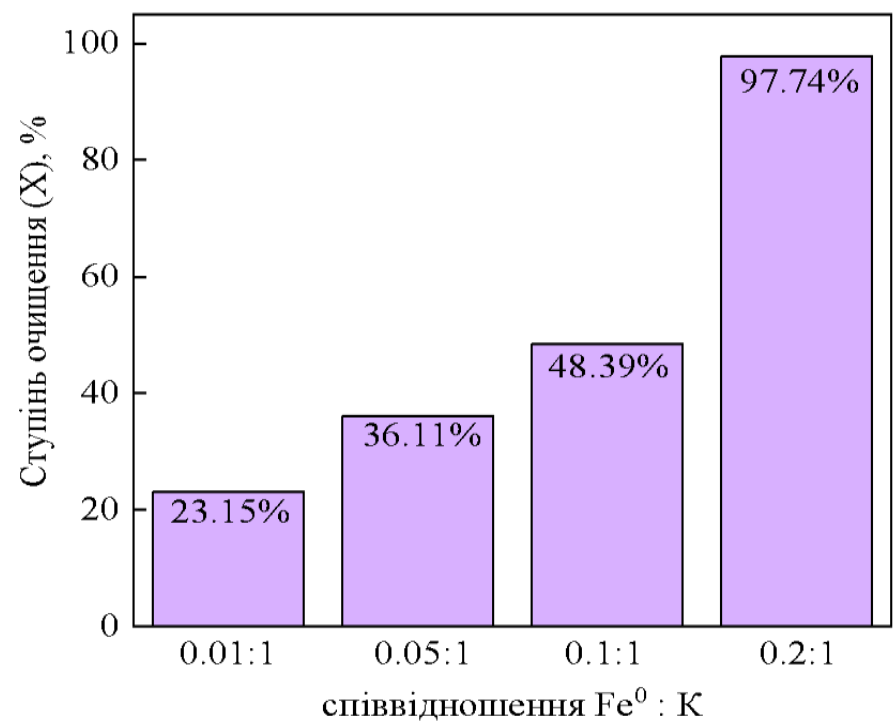

Рисунок 2. Діаграма залежності ступеня очищення $\mathrm{As}(\mathrm{V})$ від вмісту нанодисперсного $\mathrm{Fe}^{0}$ на поверхні каолініту

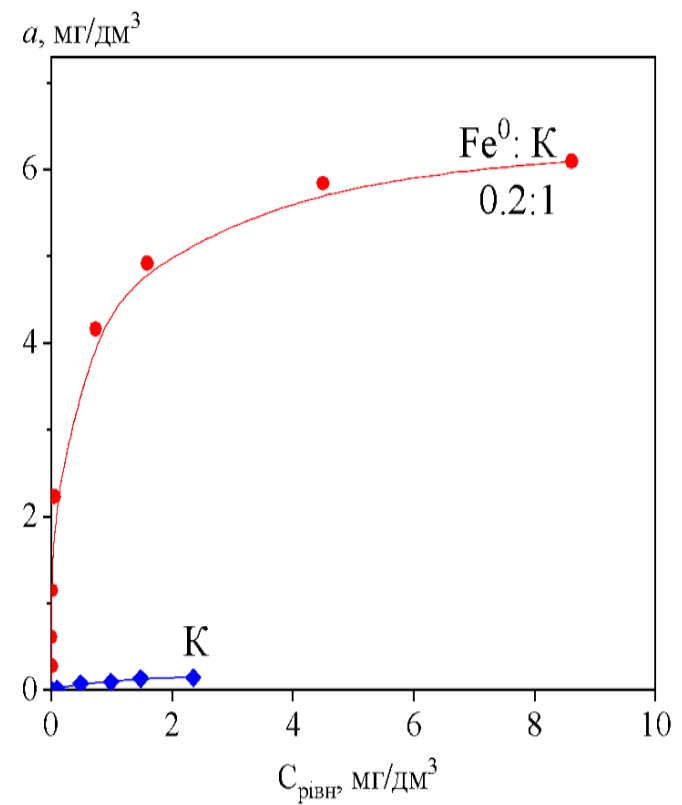

Рисунок 3. Ізотерми сорбції As(V) на вихідному та модифікованому каолініті 
Ізотерми сорбції $\mathrm{As}(\mathrm{V})$ на вихідному і модифікованому зразках каолініту наведені на рис. 3. Отримані дані вказують на те, що сорбент з нанесеним шаром $\mathrm{Fe}^{0}$ проявляє значно більшу сорбційну здатність по відношенню до арсенат-іонів, ніж природний мінерал. Так, величина максимальної сорбції арсену на композиті складає 6,2 мг/г, а на каолініті - лише 0,1 мг/г.

Таким чином, сорбційні матеріали на основі каолініту та нанорозмірного нульвалентного заліза ефективно видаляють сполуки арсену (V) із забруднених вод. Нанесення шару $\mathrm{Fe}^{0}$ на поверхню глинистого мінералу значно підвищує сорбційну здатність каолініту по відношенню до аніонних форм неорганічних забруднювачів.

\section{Література:}

1. Линник П.Н. Мышьяк в природных водах: формы нахождения, особенности миграции, токсичность (обзор). Гидробиологический журнал. 2015. 51, № 4. C.91-116. URL: http://dspace.nbuv.gov.ua/handle/123456789/126284

2. Oremland R.S., Stolz J.F. The Ecology of Arsenic. Science. 2003. 300. P.939-944. https://doi.org/10.1126/science.1081903

3. Li S., Wang W., Liang F., Wei-xian Zhang. Heavy metal removal using nanoscale zero-valent iron (nZVI): Theory and application. J. Hazard. Mater. 2017.332. P.163-171. https://doi.org/10.1016/j.jhazmat.2016.01.032

4. Тобілко В.Ю., Маковецький О.Л., Ковальчук І.А., Корнілович Б.Ю. Очищення вод від хрому (VI) та урану (VI) з використанням іммобілізованого нанодисперсного $\mathrm{Fe}^{0}$. CхідноЄвропейський журнал передових технологій. $2015 . \quad 5 / 10 \quad$ (77). С.34-40. https://doi.org/10.15587/1729-4061.2015.48885

5. Ковальчук І.А., Тобілко В.Ю., Бондарєва А.І., Холодько Ю.М., Корнілович Б.Ю. Очищення вод від іонів важких металів із використанням нанорозмірних $\mathrm{Fe}^{0} /$ каолініт композитів. Допов. Нац. акад. наук Укр. 2020. 11. https://doi.org/10.15407/dopovidi2020.11.096

6. Тобілко В.Ю., Корнілович Б.Ю. Синтез та сорбційні властивості композиційних матеріалів на основі нанорозмірного $\mathrm{Fe}^{0}$. Східно-Свропейський журнал передових технологій. 2015. 4/5 (76). C. 22-27. https://doi.org/10.15587/1729-4061.2015.46580

7. Zhang X., Lin Sh., Chen Z., Megharaj M., Naidu R. Kaolinite-supported nanoscale zerovalent iron for removal of $\mathrm{Pb}^{2+}$ from aqueous solution: reactivity, characterization and mechanism. Water Res. 2011. 45, №11. P.3481-3488. 10.1016/j.watres.2011.04.010 